\title{
Performance of Semi-dry Anaerobic Digestion of Organic Solid Waste in Mesophilic Continuous Operation
}

\author{
B. Sajeena Beevi*, G. Madhu** and Praseetha P. Nair* \\ *Department of Chemical Engineering, Govt. Engineering College, Thrissur-680 009, Kerala, India \\ **Division of Safety \& Fire Engineering, School of Engineering, Cochin University of Science and Technology, \\ Kochi-682 022, Kerala, India \\ †Corresponding author: B. Sajeena Beevi; sajeenanazer@gmail.com
}

Nat. Env. \& Poll. Tech. Website: www.neptjournal.com

Received: 07-05-2020

Revised: 20-06-2020

Accepted: 26-06-2020

Key Words:

Anaerobic digestion Municipal solid wastes Mesophilic condition Biogas

\begin{abstract}
The purpose of this study was to evaluate the performance of anaerobic digestion of organic fraction of municipal solid waste to biogas in a mesophilic $\left(32^{\circ} \mathrm{C}\right)$ continuous digester at a total solid concentration (TS) of $12 \%$. The digester was operated with different organic loading rates and constant retention time. The performance of the reactor was evaluated using parameters like $\mathrm{pH}$, volatile fatty acid (VFA), alkalinity, chemical oxygen demand (COD), total organic carbon (TOC), ammonia- $\mathrm{N}$ and biogas yield. During the reactor's start-up period (first phase), the process is stable and there is no inhibition occurred. In the second phase, the reactor was fed in continuous mode with different organic loading rates and constant retention time. The highest volatile solid (VS) degradation of $65.9 \%$, with specific biogas production of 368 L. $\mathrm{kg}^{-1} \mathrm{VS}$ fed was achieved with organic loading rate (OLR) of $3.1 \mathrm{~kg} \mathrm{VS} . \mathrm{m}^{-3} \cdot \mathrm{d}^{-1}$ and a retention time of 30 days.
\end{abstract}

\section{INTRODUCTION}

Municipal solid waste (MSW) generation is significantly increasing in the Indian urban area and is creating enormous waste disposal problems in the recent past (Rao \& Singh 2004). More than $90 \%$ of the municipal solid waste generated in India is dumped in an unsatisfactory way, which creates environmental hazards to water, air and land. In general, the organic fraction of municipal solid waste (OFMSW) in India is about 40-60\% (Mufeed et al. 2008, Visvanathan et al. 2004). In Kerala, around $70 \%$ of the waste is compostable organics enabling a high level of recycling in the form of manure or fuel. Anaerobic digestion is widely being practiced as a major treatment option for disposal of organic fraction of municipal solid waste. It mainly combines with the energy recovery benefits, greenhouse gas mitigation and produces stable end products, which can be further upgraded as compost for soil applications (Forster-Carneiro et al. 2008, Walker et al. 2009).

Anaerobic digestion is a biological process wherein a diverse group of microorganisms convert the complex organic matter into a simple and stable end products in the absence of oxygen (De Baere 2000). The main advantages of this process are the low level of sludge generation, lower energy consumption and increased level of methane production. The main drawback is the slow rate of the process.
Several research groups have developed anaerobic digestion processes using different organic substrates (Mata-Alvarez et al. 1992, Gallert et al. 2003). In general, anaerobic digestion systems are broadly categorized under wet $(<10 \%$ total solids) or dry $\left(>20 \%\right.$ total solids), mesophilic $\left(35-40^{\circ} \mathrm{C}\right)$ or thermophilic $\left(>55^{\circ} \mathrm{C}\right)$, batch or continuous and single or two-stage systems (Yabu et al. 2011, Forster-Carneiro et al. 2008). The amenability of substrate for bio gasification, gas yield-organic loading relationships, bioprocess conversion efficiency and process inhibitory parameters vary from substrate to substrate, and also for different environmental and operating conditions such as $\mathrm{pH}$, temperature, type and quality of the substrate, mixing, retention time etc. In this view, anaerobic digestion of solid waste is a process that is rapidly reaching to new advances especially in the area of dry anaerobic fermentation and has become a major focus of interest in waste management throughout the world. The purpose of this study was to analyse the performance of semidry anaerobic digestion of OFMSW in a single-stage pilot scale reactor in a continuous mode of operation at mesophilic condition $\left(32^{\circ} \mathrm{C}\right)$. In this experiment, the optimization of the pilot scale reactor treating OFMSW was performed by testing different organic loading rates (OLRs). The study was started with a start-up phase (batch mode of operation) followed by continuous operation. In continuous operation, the effect of various organic loading rates on the stability 
and performance of the reactor was evaluated at a constant retention time.

\section{MATERIALS AND METHODS}

\section{Feedstock and Inoculum Preparation}

Fresh organic fractions of MSW and inoculum were used as feed to the bioreactor. The organic fraction of MSW consists of food waste, fruit waste, vegetable waste from nearby vegetable market and household. The composition of the substrate was as follows: vegetable waste (35\%), fruits (25\%), food waste (37\%) and paper (3\%). The wastes were sorted and shredded, then mixed several times in laboratory and kept at $4{ }^{\circ} \mathrm{C}$ until used for processing (Rodriguez et al. 2017, Kim et al. 2002). The inoculum used in this study was fresh cattle dung which contains all the required microbes essential for anaerobic digestion process. The percentage of inoculation for acidogenic fermentation of organic urban wastes is approximately $30 \%(\mathrm{w} / \mathrm{w})$. The $\mathrm{pH}$, total solids and volatile solids of the inoculum were $6.5,26.2 \%$ and $82.5 \%$ respectively. The characteristics of the substrate and feed are given in Table 1.

\section{Experimental Set-up}

The experiments were performed in a pilot scale reactor. The digester, made of transparent acrylic sheet, was designed for a total volume of $36.8 \mathrm{~L}$ and working volume ( $80 \%$ of total volume) of $29.4 \mathrm{~L}$. The lower portion of the reactor was of conical shape making the discharge of drain leachate easy. A perforated plate was provided above this conical bottom. A bottom pipe was connected to collect the leachate produced and the pipe was connected to a peristaltic pump which was used for recirculation purpose. To obtain a homogeneous suspension, liquid from the bottom of the reactor was withdrawn by a peristaltic pump and recirculated through the top of the reactor. Waste is fed through a hopper connected on the top of the reactor. A wet gas meter (INSCIN) is provided at the gas outlet pipe to measure the biogas flow via a water seal. As per the required waste load, daily feeding was done from the top while almost the same quantity of the digestate was removed from the reactor through digestate outlet as shown in Fig. 1 in continuous operation. The system was operated in semi-continuous mode with feeding one time per day. Fig. 1 shows the experimental set-up.

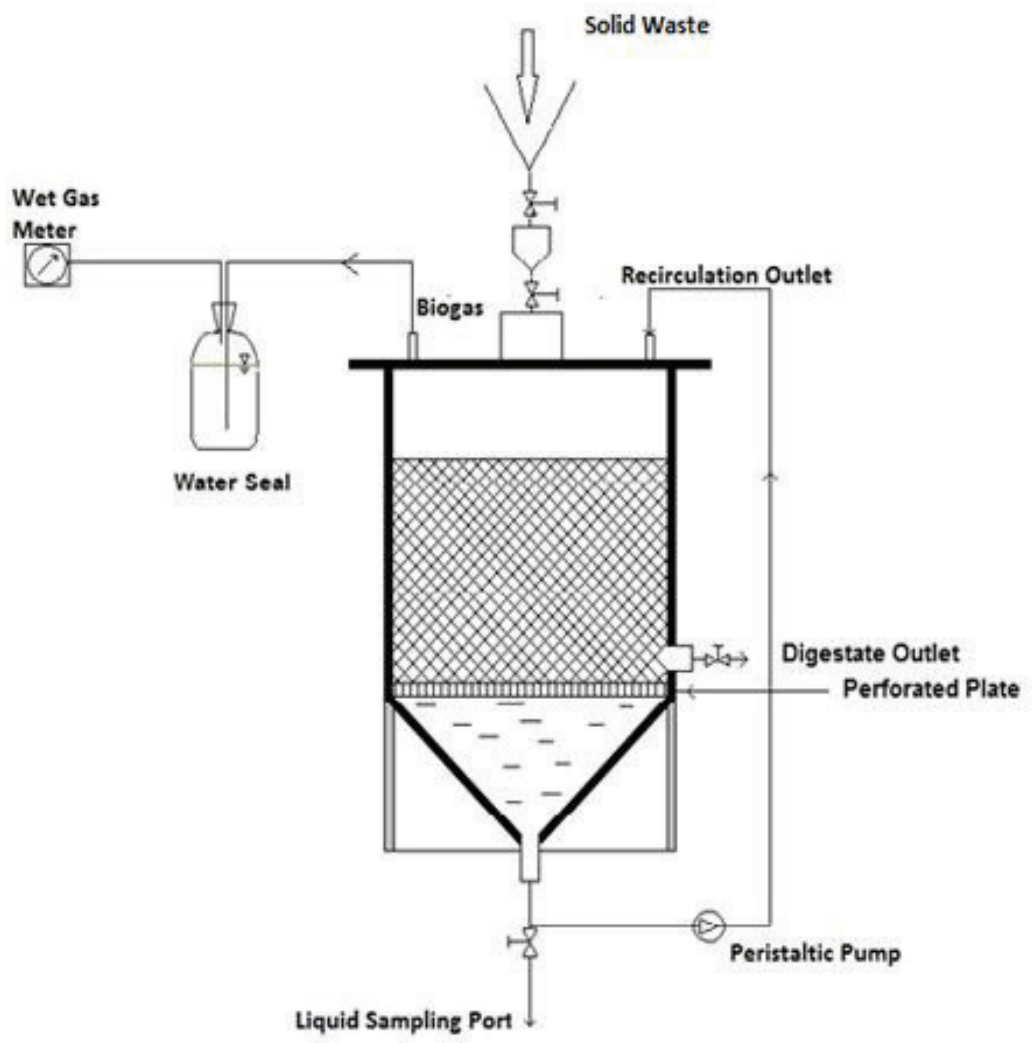

Fig. 1: Pilot-scale experimental setup of semi-dry anaerobic digester. 
Table 1: Characteristics of the substrate and feed during the start-up of the pilot experiment.

\begin{tabular}{|lll|}
\hline Parameter & OFMSW & Feed \\
\hline $\mathrm{pH}$ & 6.12 & 6.65 \\
$\mathrm{TS}(\%)$ & 19.02 & 12.30 \\
$\mathrm{VS}(\%)$ & 85.65 & 85.12 \\
VFA (meq.L $\left.{ }^{-1}\right)$ & 10.85 & 10.57 \\
COD (mg.L $\left.{ }^{-1}\right)$ & 35230 & 36018 \\
TKN (g.L $\left.{ }^{-1}\right)$ & 1.04 & 1.06 \\
TOC $\left(\mathrm{g} . \mathrm{L}^{-1}\right)$ & 22.49 & 24.5 \\
\hline
\end{tabular}

\section{Experimental Condition}

In this experiment, the optimization of semi-dry anaerobic digestion at mesophilic temperature $\left(32^{\circ} \mathrm{C}\right)$ was studied by varying the OLR. The study included both start-up operation as well as a continuous operation. The details of experimental conditions are given in the following subsections.

Start-up operation: Fresh organic fractions of MSW and inoculum were used as feed to the bioreactor. For the startup operation, the prepared feedstock was loaded into the reactor after mixing it well with the inoculum. The reactor was initially loaded with $12 \mathrm{~kg}$ of feedstock and $3.6 \mathrm{~kg}$ of inoculum source. Water was added to obtain the desired total solid concentration. The total solid concentration of the feed was $12 \%$. The system was operated without loading any additional feedstock for the first 50 days and it is considered as start-up phase. During the initial start-up phase, the system $\mathrm{pH}$ was neutralized using commercial caustic soda solution $(6 \mathrm{~N} \mathrm{NaOH})$ for quick onset of methanogenesis in the digester. To obtain a homogeneous suspension, leachate from the bottom of the reactor was recirculated by the peristaltic pump at the rate of $0.08 \mathrm{~L} / \mathrm{min}$ for 6 hours daily.
Table 2: Operating conditions of pilot scale experimental reactor.

\begin{tabular}{|llll|}
\hline Run & $\begin{array}{l}\text { Loading rate } \\
\left(\mathrm{kg} . d a y^{-1}\right)\end{array}$ & $\begin{array}{l}\text { OLR } \\
\left(\mathrm{kg} \mathrm{VS} . \mathrm{m}^{-3} \cdot \mathrm{d}^{-1}\right)\end{array}$ & $\begin{array}{l}\text { Retention } \\
\text { time (day) }\end{array}$ \\
\hline Start up & - & - & 50 \\
Continuous 1 & 0.85 & 3.1 & 30 \\
2 & 1.3 & 4.2 & 30 \\
3 & 1.5 & 5.65 & 30 \\
\hline
\end{tabular}

During this period, the system was continuously monitored for the fluctuations in process parameters such as biogas rate, ammonia-N, chemical oxygen demand (COD), total organic carbon (TOC), volatile fatty acids (VFA), alkalinity and $\mathrm{pH}$. The $\mathrm{pH}$ of the digestate was analysed every 2 days, whereas all other parameters were analysed once in a week to interpret the process performance.

Continuous operation: The reactor was operated in a continuous mode from day 51 onwards by loading the reactor with designed OLRs. As detailed in Table 2, the feedstock was loaded into the reactor with different OLRs of 3.1, 4.2 and $5.65 \mathrm{kgVS} . \mathrm{m}^{-3} \cdot \mathrm{d}^{-1}$ in three consecutive runs (1 to 3 ) with a constant retention time of 30 days. Each run was continued until the biogas yield attained to its steady-state, with no further increment, in the digester. To obtain a homogeneous suspension, leachate from the bottom of the reactor was recirculated using the peristaltic pump at the rate of $0.08 \mathrm{~L} . \mathrm{mt}^{-1}$ for $6 \mathrm{hrs}$. At each feeding, one part of the fresh feedstock was mixed up with the two parts (wt./wt. basis) of the digestate collected from the reactor. As per the required waste load, daily feeding was done from the top while almost the same quantity of the digestate was removed from the reactor. Feeding and the digestate withdrawal were done once in a day. During this period, the system was continuously monitored for the fluctuations in process parameters such as biogas

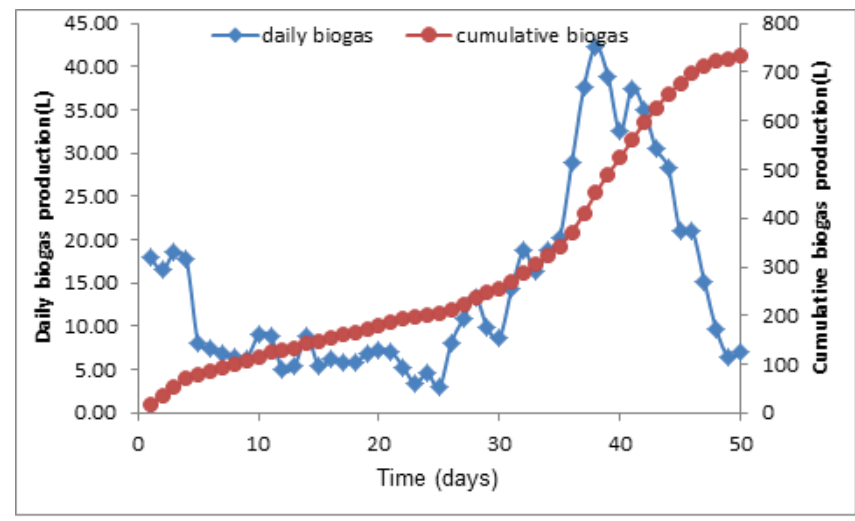

Fig. 2: Daily and cumulative biogas production during the start-up period. 
rate, ammonia-N, COD, VFA, alkalinity and $\mathrm{pH}$ as well as other digestate parameters (TS, VS and TOC). The $\mathrm{pH}$ was measured every 2 days, whereas all other parameters were analysed once to twice a week to interpret the process performance. Operating Conditions of the pilot scale experimental reactor is shown in Table 2.

\section{Analytical Methods}

The parameters analysed for the characterization of substrates were as follows: Total solids (TS), volatile solids (VS), $\mathrm{pH}$, VFA, total Kjeldahl nitrogen (TKN), and total organic carbon (TOC). Following quantities were monitored during the digestion process: $\mathrm{pH}, \mathrm{VFA}$, alkalinity, $\mathrm{NH}_{3}-\mathrm{N}, \mathrm{COD}$ and TOC. All analytical determinations were estimated according to the procedures recommended by APHA (1998). pH was measured using a digital $\mathrm{pH}$ meter ( $\mu \mathrm{pH}$ System 362). TS samples were dried in an oven at $105-110^{\circ} \mathrm{C}$, and for VS, the ash waste was dried in a muffle furnace at $500 \pm 50^{\circ} \mathrm{C}$. TKN and $\mathrm{NH}_{3}-\mathrm{N}$ content were examined by the spectrophotometer
(HITACHI, U-2900 UV/VIS spectrophotometer). VFA and alkalinity were determined using a simple titration method (Anderson \& Yang 1992). TOC analysis was carried out using Shimadzu TOC-LCPH/CPN analyser for non-purgeable organic carbon as per the standard methods.

\section{RESULTS AND DISCUSSION}

This study was conducted in two phases, namely the reactor start-up (Phase 1) and continuous operation (Phase 2).

\section{Phase 1: Performance of the Reactor During Start-up}

Digestion during start-up ran for a period of 50 days. Biogas production is the primary indicator to evaluate the performance efficiency of the reactor. Fig. 2 indicates the daily and cumulative biogas production, where, the biogas production was high at the beginning which was due to the entrapped air inside the reactor. From Fig. 2, it is clear that the biogas production was low between $5^{\text {th }}$ and $23^{\text {rd }}$ days. This may be due to the reduction of $\mathrm{pH}$. So after adjusting the $\mathrm{pH}$ value in

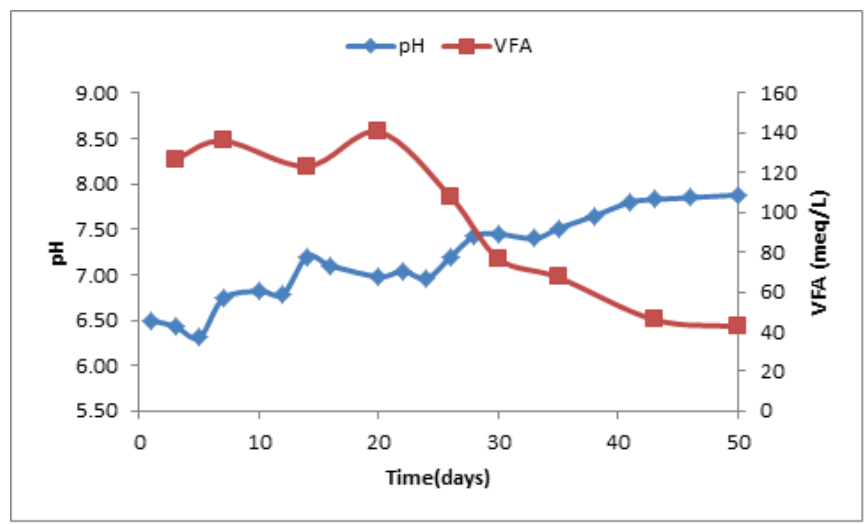

Fig. 3: Variation of $\mathrm{pH}$ and VFA during the start-up period.

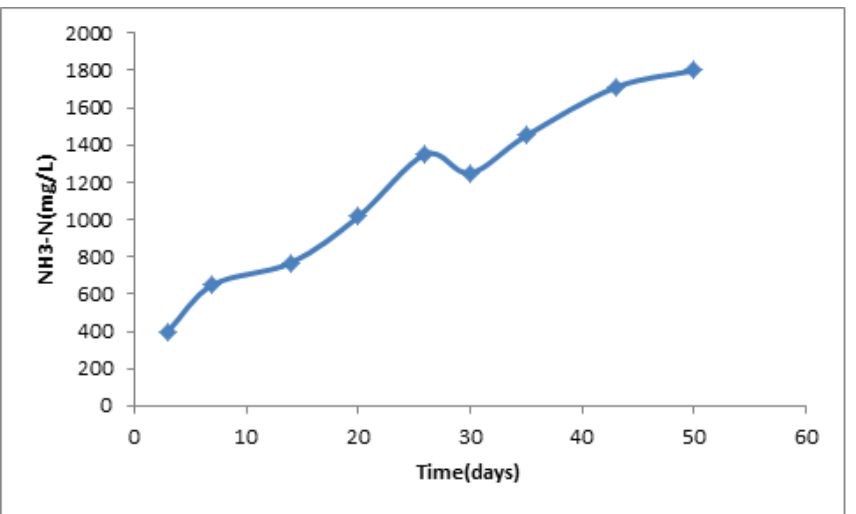

Fig. 4: Evolution of $\mathrm{NH}_{3}-\mathrm{N}$ during the start-up process. 


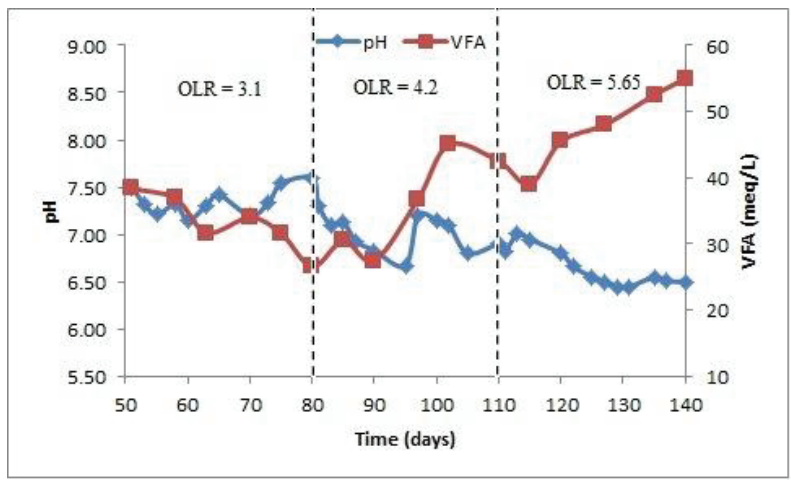

Fig. 5: Variation of $\mathrm{pH}$ and VFA during continuous loading.

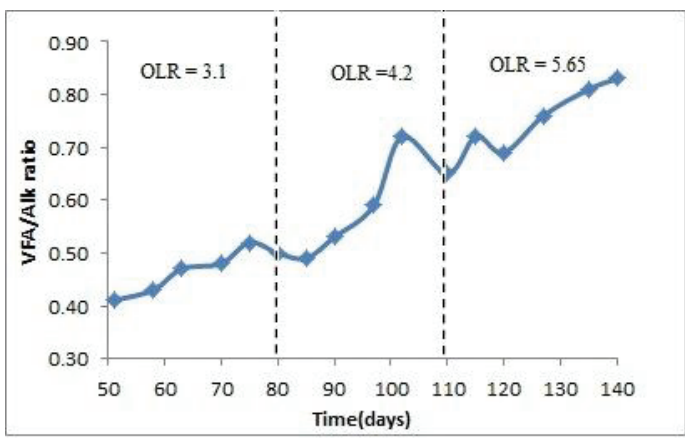

Fig. 6: VFA/Alk ratio in the digester during continuous loading.

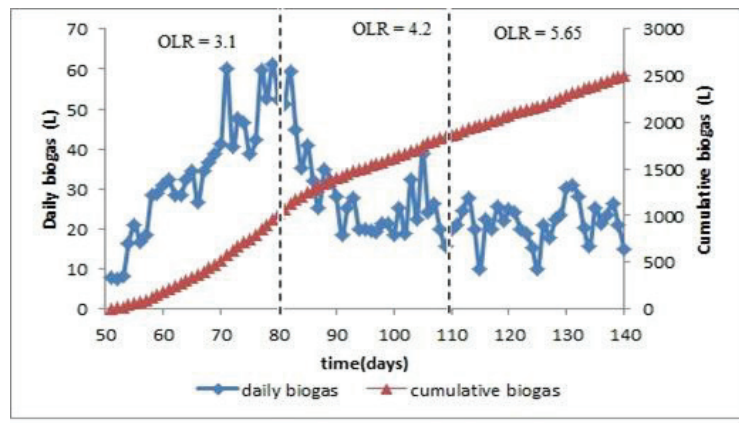

Fig. 7: Daily and cumulative biogas production during different OLRs.

the neutral range by the addition of $6 \mathrm{~N} \mathrm{NaOH}$ to the system, the production was increased. $\mathrm{pH}$ control favours the biodegradation process (Banks 2008). The highest volume of biogas produced (42.3 L.d ${ }^{-1}$ ) was achieved at day 38 . The biogas production rate decreased after day 39 indicating exhausting of readily accessible substrate for biogas production. The reactor system was run until the gas production rate peaked and then dropped below $06.5 \mathrm{~L}$ of gas per day. Then, the feeding and withdrawing mode of operation was started. During the start-up phase, approximately $735 \mathrm{~L}$ biogas was produced.

The $\mathrm{pH}$ and volatile fatty acid (VFA) variation during the start-up period are shown in Fig. 3. pH was initially 6.5, which started to decrease to 6.31 . Therefore, small quantities of $6 \mathrm{~N} \mathrm{NaOH}$ were added to the reactor periodically during days 5-24 to maintain $\mathrm{pH}$ at the near-neutral range. This can be noted as small peaks during days 5-24 in Fig. 3. From day 26 onwards, $\mathrm{pH}$ started increasing slowly; therefore, $\mathrm{NaOH}$ was not added anymore. It became stable at around 7.8 during 
days 41-50. The VFA generation in the beginning was high due to higher acidogenesis and lower methanogenic activity. The initial $\mathrm{pH}$ drop and high volatile fatty acid concentration show that the substrate contains some easily biodegradable constituent. VFA concentration was increased till $20^{\text {th }}$ day and maximum VFA concentration of 140.5 meq. $\mathrm{L}^{-1}$ was formed on the same day. After that VFA concentration was found decreased due to methanogenic activity in which the intermediate organic acids were started to convert into biogas. The concentration of VFA dropped from 140.5 meq. $\mathrm{L}^{-1}$ to 42.5 meq. $\mathrm{L}^{-1}$ in 30 days. The reason is that there was no waste feeding throughout the start-up phase (day 1-50).

The organic content of the substrate was measured in terms of COD and TOC. The significant increase in COD in leachate was observed at the beginning which was the sign of an active hydrolyse phase. The COD and TOC of the leachate were found decreasing due to the conversion of organic matter into biogas. The trend of ammonia-nitrogen $\left(\mathrm{NH}_{3}-\mathrm{N}\right)$ during the start-up process is shown in Fig. 4. In this experiment, concentrations of $\mathrm{NH}_{3}-\mathrm{N}$ were increasing due to the release of ammonia during the hydrolysis of protein. Ammonia nitrogen is an important parameter for the bu er capacity in an anaerobic reactor. With concentrations up to $1000 \mathrm{mg} / \mathrm{L}$, ammonia nitrogen stabilizes the $\mathrm{pH}$ value. Ammonia nitrogen is released during the anaerobic hydrolysis of protein, causing an increase in the $\mathrm{pH}$ value. It is evident that the ammonia nitrogen concentration $\left(>6000 \mathrm{mg} . \mathrm{L}^{-1}\right)$ indicates the inhibition of methanogens in an acclimated environment (Mata-Alvarez et al. 2000). In this study, the $\mathrm{NH}_{3}-\mathrm{N}$ concentration increased from $400 \mathrm{mg} . \mathrm{L}^{-1}$ to 1800 $\mathrm{mg} . \mathrm{L}^{-1}$. So it can be concluded that there was no inhibition of ammonia nitrogen during the AD process of this system during the start-up process.

\section{Phase 2: Continuous Operation}

In this operation, continuous feeding was applied in draw and feed mode. Experiments were conducted for three different organic loading rates of $3.1,4.2$ and $5.65 \mathrm{~kg} \mathrm{VS} . \mathrm{m}^{-3} \cdot \mathrm{d}^{-1}$ in three consecutive runs with a constant retention time of 30 days.

\section{Effect of Organic Loading Rate on Stability Parameters of The Reactor}

\section{(i) $\mathrm{pH}$ and VFA}

In the anaerobic digestion process, methanogenic bacteria are more sensitive to environmental conditions than hydrolytic and acidogenic bacteria. The first criterion that was taken into account is the $\mathrm{pH}$ value. The $\mathrm{pH}$ indicates the stability of the system and its variation also depends on the buffering capacity itself. The $\mathrm{pH}$ is an indicator of good process performance and should be above 7.0 at all times in which case the process operates successfully. With OLR of $3.1 \mathrm{~kg} \mathrm{VS} . \mathrm{m}^{-3} . \mathrm{d}^{-1}$, the system stabilized its $\mathrm{pH}$ around 7.36 with a range of 7.15-7.6 as shown in Fig.5. When the OLR was increased from 3.1 to $4.2 \mathrm{~kg} \mathrm{VS} . \mathrm{m}^{-3} . \mathrm{d}^{-1}, \mathrm{pH}$ fell to 6.8 and regulated to an average of 7.01 (6.8-7.31). As a result of a further increase in OLR to $5.65 \mathrm{~kg} \mathrm{VS} . \mathrm{m}^{-3} \cdot \mathrm{d}^{-1}$, a drastic decrease in $\mathrm{pH}$ was observed and $\mathrm{pH}$ dropped to the value of 6.5. The decline in $\mathrm{pH}$ in the starting days of each of the first two runs and most of the last run is linked to the destabilization of the system as a result of an increase in OLR. The reason is that when organic loading rate is increased, the acidogens also increase their activity and produce a high amount of VFA, as they are fast-growing. But, on the other hand, methanogens owing to their slow specific growth rate cannot utilize all the already produced VFA and need more time to build the required population size. Thus initial and a temporary decrease in $\mathrm{pH}$ occurred due to accumulation of VFA as a result of the imbalance in the microbial groups, is recovered when methanogens build their sufficient population. The decrease in $\mathrm{pH}$ is more pronounced while working with higher OLR, i.e., $5.65 \mathrm{~kg} \mathrm{VS} \cdot \mathrm{m}^{-3} \cdot \mathrm{d}^{-1}$. The reason is that the imbalance between acidogenic and methanogenic activity is more at high OLRs. The concentration of volatile fatty acids in the digestate was quite stable at an average value of 33.2 meq. $\mathrm{L}^{-1}$ (range: $26.6-38.4$ meq. $\mathrm{L}^{-1}$ ) while operating at OLR of $3.1 \mathrm{~kg} \mathrm{VS} \cdot \mathrm{m}^{-3} \cdot \mathrm{d}^{-}$. When OLR was increased to $4.2 \mathrm{~kg} \mathrm{VS} . \mathrm{m}^{-3} . \mathrm{d}^{-}$, VFA concentration started to increase and reached a maximum value of $45 \mathrm{meq} / \mathrm{L}$ with an average value of 36.5 meq. $\mathrm{L}^{-1}$ in this run. Finally, at an OLR of $5.65 \mathrm{~kg}$ VS. $\mathrm{m}^{-3} \cdot \mathrm{d}^{-1}$, the VFA concentration increased to $55 \mathrm{meq} . \mathrm{L}^{-1}$ because of increasing organic loading rate. This trend shows the destabilization of the reactor caused by an increase in OLR. It is important to note that at the start of each OLR, the VFA started to accumulate, which is related with the imbalance of activity of microbial groups and initial temporary destabilization of the reactor as a result of an increase in OLR as discussed above in the case of $\mathrm{pH}$. Similarly, at the end of each of the first two OLRs, the concentration of VFA declined, which is a sign of stability of the system.

(ii) VFA to Alkalinity Ratio (VFA/Alk Ratio)

VFA/Alk ratio is a good indicator of digester functioning. It is shown in Fig. 6. With OLR of $3.1 \mathrm{kgVS} . \mathrm{m}^{-3} \cdot \mathrm{d}^{-1}$, this parameter remained between 0.41 and 0.52 for most of the time. This is a good range of VFA/Alk ratio for a digester to work. But at OLR of $4.2 \mathrm{~kg} \mathrm{VS} . \mathrm{m}^{-3} . \mathrm{d}^{-1}$, the average value of VFA/Alk ratio increased to 0.59 , which is still acceptable for an operating digester. However, at OLR of $5.65 \mathrm{~kg} \mathrm{VS} . \mathrm{m}^{-3} \cdot \mathrm{d}^{-1}$, VFA/Alk ratio increased to a very harmful range (0.72-0.83) because at VFA/Alk ratio of 0.8 , significant $\mathrm{pH}$ reduction and digester failure happen. 


\section{Performance of Pilot Scale Reactor At Different Loading Rate}

Biogas production: Biogas production was monitored daily. One of the main objectives of this research was to determine the performance of the $\mathrm{AD}$ process when operated at different loading rates. To evaluate this system on the effect of loading rate, biogas production, specific biogas production or biogas yield and VS reduction were taken as the indicators to assess the reactor performance of each loading rate. Fig. 7 shows the daily and cumulative biogas production during continuous loading. The average biogas production rate during runs 1 , 2 and 3 was approximately $34 \mathrm{~L} / \mathrm{d}, 28 \mathrm{~L} / \mathrm{d}$ and $21.6 \mathrm{~L}^{-\mathrm{d}^{-1}}$ respectively. It can be noted that at the end of OLR 3.1 and $4.2 \mathrm{~kg} \mathrm{VS} . \mathrm{m}^{-3} \cdot \mathrm{d}^{-1}$, the gas production rate becomes stable. This is related to stable $\mathrm{pH}$ and VFA concentration of the system at the mentioned time. The decrease in the biogas production rate was almost linear with the increase in OLR during the first two runs. But, during run 3 (i.e. OLR 5.65 $\left.\mathrm{kg} \mathrm{VS} . \mathrm{m}^{-3} \cdot \mathrm{d}^{-1}\right)$, the gas production rate did not decrease with the same rate as that of OLR. This could be explained from a drastic increase in the VFA/Alk ratio (or drop in alkalinity) during that run.

VS removal and Specific biogas production: Volatile solid reduction was taken into consideration as well to evaluate the reactor performance and stability of the digestate. VS degradation value of $65.9 \%$ was achieved when operating at OLR of $3.1 \mathrm{~kg} \mathrm{VS} . \mathrm{m}^{-3} \cdot \mathrm{d}^{-1}$. On the other hand, while loading rate 2 and 3 with increased OLR of 4.2 and $5.65 \mathrm{~kg} \mathrm{VS. \textrm {m } ^ { - }}$ ${ }^{3} . \mathrm{d}^{-1}$, VS removal were decreased to $55.2 \%$ and $43.7 \%$ respectively. Comparably, these VS reductions were lower with the result found by Castillo et al. (2006) who reported that $\mathrm{VS}$ reduction of $77.1 \%$ was obtained with the digestion time of 25 days. This lower value may be due to the reactor configuration. But, these results are similar to those obtained by Gallert \& Winter (2003). They obtained VS removal of 65 $\%$ in a thermophilic system operating at OLR of $9.5 \mathrm{~kg} \mathrm{VS.m}{ }^{-}$ ${ }^{3} \cdot \mathrm{d}^{-1}$ and $18 \%$ TS. The highest specific biogas production observed was $368 \mathrm{~L} / \mathrm{kgVS}$ fed at OLR of $3.1 \mathrm{~kg} \mathrm{VS} . \mathrm{m}^{-3} \cdot \mathrm{d}^{-1}$. As the loading rate was increased, decreases in the biogas yields $(229 \mathrm{~L} / \mathrm{kgVS}$ and $130 \mathrm{~L} / \mathrm{kgVS})$ were observed at OLR of 4.2 and $5.65 \mathrm{~kg} \mathrm{VS} . \mathrm{m}^{-3} \cdot \mathrm{d}^{-1}$ respectively. The overloading was marked by the fall in $\mathrm{pH}$ and gas yield. However, the specific biogas production of $368 \mathrm{~L} / \mathrm{kg}$ VS at OLR of 3.1 $\mathrm{kg} \mathrm{VS} . \mathrm{m}^{-3} \cdot \mathrm{d}^{-1}$ of this study is in line with the biogas yield values found in the literature. The biogas yield reported by various authors through dry anaerobic digestion of OFMSW at thermophilic conditions is in the range of $350-500 \mathrm{~L} / \mathrm{kg} \mathrm{VS}$ added (Pavan et al. 2000, Montero et al. 2010, Bolzonella et al. 2003). Similarly, biogas yield reported for water sorted organic fraction of municipal solid waste (WS-OFMSW) under mesophilic semi-dry anaerobic digestion was 423L/ $\mathrm{kg}$ VS added ( $\mathrm{Li}$ et al. 2010). It should be cautioned here that the optimum loading rate of $3.1 \mathrm{~kg} \mathrm{VS} \cdot \mathrm{m}^{-3} \cdot \mathrm{d}^{-1}$ observed here is not universal as the optimal rate depends upon the reactor configuration.

\section{CONCLUSIONS}

The present study focused on the continuous operation of semi-dry anaerobic digestion of OFMSW under mesophilic condition. In this study, an effective start-up of the anaerobic digestion with inoculum was done successfully. During the continuous operation, when the loading rate was increased, the biogas production decreased. Specific biogas production or biogas yield dropped from $368 \mathrm{~L} / \mathrm{kgVS}$ to $130 \mathrm{~L} / \mathrm{kgVS}$ when loading rates were increased from 3.1 to $5.65 \mathrm{~kg} \mathrm{VS.m}{ }^{-}$ ${ }^{3} \cdot \mathrm{d}^{-1}$. The highest VS degradation of $65.9 \%$ was obtained with OLR of $3.1 \mathrm{~kg} \mathrm{VS} . \mathrm{m}^{-3} \cdot \mathrm{d}^{-1}$ at a retention time of 30 days. From the present study, the optimum loading rate obtained for maximum biogas production was $3.1 \mathrm{~kg} \mathrm{VS} \cdot \mathrm{m}^{-3} \cdot \mathrm{d}^{-1}$.

\section{REFERENCES}

Anderson, G.K. and Yang, G. 1992. Determination of bicarbonate and total volatile acid concentration in anaerobic digesters using a simple titration. Water Environ. Res., 64: 53-59.

APHA 1998. Standard Methods for the Examination of Water and Wastewater. 20th ed., American Public Health Association, Washington, DC, USA.

Banks, C. J. and Chesshire, M. 2008. A pilot-scale comparison of mesophilic and thermophilic digestion of source segregated domestic food waste. Water Science and Technology, 58(7): 1475-1481.

Bolzonella, D., Innocenti, L., Pavan, P., Traverso, P. and Cecchi, F. 2003. Semi-dry thermophilic anaerobic digestion of the organic fraction of municipal solid waste: Focusing on the start-up phase. Bioresource Technology, 86(2): 123-129.

Castillo, M.E., Cristancho, D.E. and Arellano, V A. 2006. Study the operational condition for anaerobic digestion of urban solid wastes. Waste Management, 26: 546-556.

De Baere, L. 2000. Anaerobic digestion of solid waste: State-of-the-art. Water Science Technology, 41: 83-290.

Forster-Carneiro, T., Perez, M. and Romero, L.I. 2008. Thermophilic anaerobic digestion of source-sorted organic fraction of municipal solid waste. Bioresource Technology, 99: 6763-6770.

Gallert, C., Henning, A. and Winter, J. 2003. Scale-up of anaerobic digestion of the biowaste fraction from domestic wastes. Water Research, 37: 1433-1441.

Kim, D. and Oh, S. 2011. Continuous high-solids anaerobic co-digestion of organic solid wastes under mesophilic conditions. Waste Management, 31(9): 1943-1948.

Li, Dong, Yuan, Zhenhong and Sun, Yongming 2010. Semi-dry mesophilic anaerobic digestion of water sorted organic fraction of municipal solid waste (WS-OFMSW). Bioresource Technology, 101: 2722-2728.

Mata-Alvarez, J., Mace, S. and Llabres, P. 2000. Anaerobic digestion of organic solid wastes. An overview of research achievement and perspectives. Bioresource Technology, 74: 3-16.

Mata-Alvarez, J., Llabres, P., Cecchi, F. and Pavan, P. 1992. Anaerobic digestion of the Barcelona central food market organic wastes: Experimental study. Bioresource Technology, 39: 39-48. 
Montero, B., Garcia-Morales, J.L., Sales, D. and Solera, R. 2010. Evolution of butyric acid and the methanogenic microbial population in a thermophilic dry anaerobic reactor. Waste Management, 30(10): 1790-1797.

Mufeed, Sharholy, Kafeel, Ahmad and Gauhar, Mahmood 2008. Municipal solid waste management in Indian cities- A review. Waste Management, 28: 459-467.

Pavan, P., Battistoni, P., Mata-Alvarez, J. and Cecchi, F. 2000. Performance of thermophilic semi-dry anaerobic digestion process changing the feed biodegradability. Water Science and Technology, 41(3): 75-81.

Rao, M.S. and Singh, S.P. 2004. Bioenergy conversion studies of organic fraction of MSW: Kinetic studies and gas yield-organic loading relationships for process optimization. Bioresource Technology, 95: 173-185.

Rodriguez, C., Alaswad, A. and El-Hassan, Z. 2017. Mechanical pretreatment of waste paper for biogas production. Waste Management, 68: 157-164. Visvanathan, C., Trankler, J., Joseph, K., Chiemchaisri, C., Basnayake, B.F.A. and Gongming, Z. 2004. Municipal Solid Waste Management In Asia, Asian Regional Research Program On Environmental Technology (ARRPET). Asian Institute of Technology Publications, ISBN: 974-417-258-1.

Walker, L., Charles, W. and Cord-Ruwisch, R. 2009. Comparison of static, in-vessel composting of MSW with thermophilic anaerobic digestion and combinations of the two processes. Bioresource Technology, 100(16): 3799-3807.

Yabu, H., Sakai, C., Fujiwara, T., Nishio, N. and Nakashimada, Y. 2011. Thermophilic two-stage dry anaerobic digestion of model garbage with ammonia stripping. J. Bioscience and Bioengineering, 111: 312-319. 